\title{
Surgical Treatment of the Displaced Proximal Humeral Fractures in Adults with Philos Plate
}

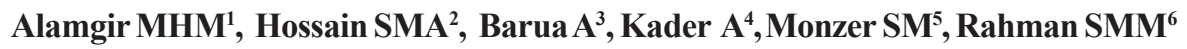

Conflict of Interest: None Received: $09-05-2018$

Accepted: $16-10-2018$ www.banglajol.info/index.php/JSSMC

Key Words:

Bone plate, screw, humeral fractures.

\begin{abstract}
Aim: To evaluate the treatment outcome of Philos plate fixation for displaced proximal humeral fractures in 17 patients.

Methods: This was a prospective study with 17 patients, 11 women, 6 men with average age $62 y$ r having displaced proximal humeral fractures fixed with Philos plate. All the fractures were closed and no associated injuries, classified as 2 part $(n=12), 3$ part $(n=3), 4$ part $(n=2)$ according to Neer classification. All patients were evaluated clinically, functionally and radiologically using the Constant Shoulder Score.
\end{abstract}

Results: Patients were followed up for 6 to 24 months. All the fractures healed except one which was four part fracture in $65 y \mathrm{r}$ woman. The fracture was in varus position and screw penetration of humeral head at six week. Revision surgery was done and eventually fracture united.

Conclusion: Philos plate fixation is a good stable construct with minimal metal work problems and permit early movement.

[J Shaheed Suhrawardy Med Coll 2018; 10(2): 80-82] DOI: https://doi.org/10.3329/jssmc.v10i2.41162

\section{Introduction}

Proximal humeral fracture may be defined as fractures occurring at proximal to surgical neck of humerus. ${ }^{1}$ It is the commonest fracture of shoulder girdle in adult. ${ }^{2}$ Proximal humeral fractures composed $4 \%$ of all fractures and nearly one half of all humeral fractures. ${ }^{3}$

There are many options for treating proximal humeral fractures. Minimally displaced proximal humeral stable fractures are being treated conservatively with good results. $^{4}$

Displaced and unstable fractures are difficult to manage and have a high morbidity. The ultimate goal of treatment

1. Dr. M.H.M. Alamgir, Associate Professor, Department of Ortho-surgery, Shaheed Suhrawardy Medical College, Dhaka

2. Dr. S.M. Amir Hossain, Associate Professor, Department of Ortho-surgery, Shaheed Suhrawardy Medical College, Dhaka

3. Dr. Anupam Barua, Junior Consultant, Department of Orthosurgery, Shaheed Suhrawardy Medical College Hospital, Dhaka

4. Dr. Abdul Kader, Senior Consultant, Department of Orthosurgery, Shaheed Sheikh Abu Naser Specialized Hospital, Khulna

5. Dr. Salauddin M. Monzer, Medical Officer, Department of Orthosurgery, Shaheed Suhrawardy Medical College Hospital, Dhaka

6. Dr. S.M. Mosheeur Rahman, Assistant Registrar, Department of Ortho-surgery, Shaheed Suhrawardy Medical College Hospital, Dhaka

Correspondence to: Dr. M.H.M. Alamgir, Associate Professor, Department of Ortho-surgery, Shaheed Suhrawardy Medical College, Dhaka is to have a painless stable functional shoulder .Different methods are described namely Kirshner wire fixation, suture fixation, External fixation, Tension Band Wiring, Rush nail fixation, intramedullary fixation and prosthetic replacement. ${ }^{5-11}$

Locking plate fixation provides angular and axial stability minimizes risks of screw toggle and pull out as well as loss of reduction. Divergent or convergent locked screw improves the pull out resistance of the whole construct. ${ }^{11}$ Locking plate fails at greater load than nonlocking plates. ${ }^{12}$

Philos (Proximal Humeral Locking system) plates are preshaped and precontoured. Locking compression plates with an aiming device for insertion of the locking screw and positioning of the plate to prevent impingement. We evaluate the treatment outcome of Philos plate fixation for displaced proximal humeral fractures in adults.

\section{Materials and Methods}

This was a prospective study carried out at Shaheed Suhrawardy Medical College Hospital, Dhaka from January 2015 to December 2017. There were 17 patients out of which 11 women and 6 men with average age $62 \mathrm{yrs}$. All patients having displaced proximal humeral fractures were fixed with Philos plate. Fractures were due to fall on ground $(n=10)$ and road traffic accidents $(n=7)$. All the fractures were closed and have no associated injury. All fractures 
were classified as 2 part $(n=12), 3$ part $(n=3)$ and 4 part $(\mathrm{n}=2)$ according to Neer classification. ${ }^{13}$

A deltopectoral incision was made with patient in supine position. Fractures were reduced and temporarily fixed with Kirshner wires and sutures. Reduction was checked under image intensifier. Philos plate was applied with at least 4 locking proximal screws and 4 nonlocking distal screws. Passive assisted movement were started on day1 followed by active assisted exercise after 3 weeks .All the patients were assessed clinically, functionally radiological using the Constant Shoulder Score. ${ }^{14}$

\section{Results}

Patients were followed up for 6 to 24 months (mean 13 months).All the fractures were united except one in $65 \mathrm{yr}$ woman with a 4 part fracture. There was screw penetration of humeral head at 6 weeks. Eventually she developed nonunion and revision surgery was done. Ultimately fracture united. There was no wound infection. The mean Constant Shoulder Score was 68 with a range of 40 to 85 . 7 patients having score more than 75 , Seven patients having were between 50 to 75,3 patients below 50 . Constant scores in 2part, 3part and 4part fractures were compared in Table.

\section{Table-I}

\section{Comparism of Constant Scores}

\begin{tabular}{lccc} 
Constant & \multicolumn{3}{c}{ No.(\%) of patients } \\
Score & $\begin{array}{c}\text { 2-part fracture } \\
(\mathrm{n}-12)\end{array}$ & 3-partfracture & 4-part fracture \\
& $(\mathrm{n}-3)$ & $(\mathrm{n}-2)$ \\
\hline Mean(range) & $75(50-85)$ & $66(40-84)$ & $45(41-49)$ \\
$>75$ & $6(50)$ & $1(33)$ & $0(0)$ \\
$50-75$ & $6(50)$ & $1(33)$ & $0(0)$ \\
$<50$ & $0(0)$ & $1(33)$ & $2(100)$ \\
\hline
\end{tabular}

\section{Discussion}

Non-operative treatment for displaced proximal humeral fractures is still advocated, patient satisfaction is high ,especially in those with 2 part fractures, ${ }^{15}$ in elderly patients with low functional demand even with poor reduction on radiograph and low Constant score. ${ }^{16}$ Surgical treatment with minimal soft tissues stripping enables satisfactory reduction, stable fixation and early mobilization but the technical difficulties including poor bone stock, minimum subchondral bone in humeral head and excessive soft damage. The most common risks include screw cut out back out, penetration of humeral head, loss of reduction, avascular humeral head necrosis and subacromial impingement
Plant Tan plate fixation with 2 cancellous screws resulted in a $100 \%$ failure rate in elderly osteoporotic patients. ${ }^{17}$ Fixation with 2 one-third tubular plates resulted in a complication rate of $12 \%$ including loosening of implants, avascular necrosis, subchondral impingement, frozen shoulder and fracture redisplacement. ${ }^{18}$ Tension band wiring and nonoperative treatment had similar functional results. ${ }^{19}$ Tension band wiring was superior in 4 part fractures and nonoperative in 3 part fractures. ${ }^{19}$

AO plate fixation had also a high complication rate including deep infection (4/32), impingement necessitating implant removal $(5 / 32)$ and avascular necrosis $(4 / 32){ }^{5}$ Cloverleaf plate fixation achieved good results but a hemiarthroplasty was recommended in elderly patients with poor bone stock. ${ }^{20}$ Although hemiarthroplasty achieved good pain relief, its functional results were unpredictable and its strength poor. ${ }^{21,22}$

Reverse prosthesis fixation achieved better functional out come. ${ }^{23}$ Polarus nail fixation yields good results ${ }^{8}$ and used in combine neck and shaft fractures. ${ }^{24}$ But the complication rate was high (proximal screw loosening $3 / 20$, revision surgery $2 / 20$, lateralmetaphyseal communition predisposes to implant failure)..$^{25}$

Locking proximal humeral plate fixation achieved acceptable results even in osteoporotic bone but nonunion, implant failure, avascular necrosis of humeral head and revision surgery also have been reported. ${ }^{26,27,28,29,30}$ Angle stabilizing plates fixation were not necessarily associated with good functional outcome. ${ }^{29}$ Caution is needed in cases of medial communition during locking plate fixation. ${ }^{31}$

Our study, Philos plate fixation provided a stable good construct with minimal metal works problems and enabled early range of motion exercises to achieve acceptable functional results. Nonetheless, the choice of treatment should be based on patient age, functional needs, bone quality, fracture personality and surgeon's preference. Prospective randomized trials are needed to compare different methods of fixation.

\section{Acknowledgement}

I acknowledged all my patients their relatives,all stuff of inpatient departments and operation theatre,others who helped me preparing manuscript.I thank my family members especially my wife.

\section{References}

1. Kim SH, Szabo RM, Marder RA. Epidemiology of humerus fractures in the United States: Nationwide emergency department sample, 2008. Arthritis Care Res (Hoboken). 2012;64(3):407-414. 
2. Ogiwara N, Aoki M, Okamura K, et al. Ender nailing for unstable surgical neck fractures of the humerus in elderly patients. Clin Orthop Relat Res. 1996;(330):173-180.

3. Horak J, Nilsson BE. Epidemiology of fracture of the upper end of the humerus. Clin Orthop Relat Res. 1975;(112):250-253.

4. Young, TB, Wallace, WA. Conservative treatment of fractures and fracture-dislocations of the upper end of the humerus. J Bone Joint Surg Br 1985;67:373-7. en, n.

5. Kristiansen, B, Christensen, SW. Plate fixation of proximal humeral fractures. Acta Orthop Scand 1986;57:320-3. Google Scholar, Crossref, Medline

6. Kristiansen, B, Kofoed, H. External fixation of displaced fractures of the proximal humerus. Technique and preliminary results. J Bone Joint Surg Br 1987;69:643-6., Medline

7. Park, MC, Murthi, AM, Roth, NS, Blaine, TA, Levine, WN, Bigliani, LU. Two-part and three-part fractures of the proximal humerus treated with suture fixation. J Orthop Trauma 2003:17:319-25. Google Scholar, Crossref, Medline, ISI

8. Rajasekhar, C, Ray, PS, Bhamra, MS. Fixation of proximal humeral fractures with the Polarus nail. J Shoulder Elbow Surg 2001;10:7-10. Google Scholar, Crossref, Medline, ISI

9. Robinson, CM, Page, RS, Hill, RM, Sanders, DL, CourtBrown, CM, Wakefield, AE. Primary hemiarthroplasty for treatment of proximal humeral fractures. J Bone Joint Surg Am 2003;85:1215-23. Google Scholar, Crossref, Medline, ISI

10. Sadowski, C, Riand, N, Stern, R, Hoffmeyer, P. Fixation of fractures of the proximal humerus with the PlantTan Humerus Fixator Plate: Early experience with a new implant. J Shoulder Elbow Surg 2003;12:148-51. Google Scholar, Crossref, Medline, ISI

11. Wagner, M. General principles for the clinical use of the LCP. Injury 2003;34(Suppl 2):B31-42. Google Scholar, Crossref, Medline, ISI

12. Walsh, S, Reindl, R, Harvey, E, Berry, G, Beckman, L, Steffen, T. Biomechanical comparison of a unique locking plate versus a standard plate for internal fixation of proximal humerus fractures in a cadaveric model. Clin Biomech (Bristol, Avon) 2006;21:1027-31. Google Scholar, Crossref, Medline, ISI

13. Neer, CS. Displaced proximal humeral fractures. I. Classification and evaluation. J Bone Joint Surg Am 1970;52:1077-89. Google Scholar, Crossref, Medline, ISI

14. Constant, CR, Murley, AH. A clinical method of functional assessment of the shoulder. Clin Orthop Relat Res 1987; 214:160-4. Google Scholar

15. Rasmussen, S, Hvass, I, Dalsgaard, J, Christensen, BS, Holstad, E. Displaced proximal humeral fractures: Results of conservative treatment. Injury 1992;23:41-3. Google Scholar, Crossref, Medline, ISI

16. Zyto, K. Non-operative treatment of comminuted fractures of the proximal humerus in elderly patients. Injury 1998;29:349-52. Google Scholar, Crossref, Medline, ISI

17. Sadowski, C, Riand, N, Stern, R, Hoffmeyer, P. Fixation of fractures of the proximal humerus with the PlantTan Humerus Fixator Plate: Early experience with a new implant. J Shoulder Elbow Surg 2003;12:148-51. Google Scholar, Crossref, Medline, ISI

18. Wanner, GA, Wanner-Schmid, E, Romero, J, Hersche, O, von Smekal, A, Trentz, O. Internal fixation of displaced proximal humeral fractures with two one-third tubular plates. J Tauma 2003;54:536-44. Google Scholar, Medline, ISI
19. Ilchmann, T, Ochsner, PE, Wingstrand, H, Jonsson, K. Nonoperative treatment versus tension-band osteosynthesis in three-and four-part proximal humeral fractures. A retrospective study of 34 fractures from two different trauma centers. Int Orthop 1998;22:316-20. Google Scholar, Crossref, Medline, ISI.

20. Esser, RD. Treatment of three- and four-part fractures of the proximal humerus with a modified cloverleaf plate. J Orthop Trauma 1994;8:15-22. Google Scholar, Crossref, Medline, ISI

21. Goldman, RT, Koval, KJ, Cuomo, F, Gallagher, MA, Zuckerman, JD. Functional outcome after humeral head replacement for acute three- and four-part proximal humeral fractures. J Shoulder Elbow Surg 1995;4:81-6. Google Scholar, Crossref, Medline

22. Gronhagen, CM, Abbaszadegan, H, Revay, SA, Adolphson, PY. Medium-term results after primary hemiarthroplasty for comminute proximal humerus fractures: A study of 46 patients followed up for an average of 4.4 years. J Shoulder Elbow Surg 2007;16:766-73. Google Scholar, Crossref, Medline, ISI

23. Bufquin, T, Hersan, A, Hubert, L, Massin, P. Reverse shoulder arthroplasty for the treatment of three- and four-part fractures of the proximal humerus in the elderly: A prospective review of 43 cases within a short-term follow-up. J Bone Joint Surg Br 2007;89:516-20. Google Scholar, Crossref, Medline

24. Adedapo, AO, Ikpeme, JO. The results of internal fixation of three- and four-part proximal humeral fractures with the Polarus nail. Injury 2001;32:115-21. Google Scholar, Crossref, Medline, ISI

25. Agel, J, Jones, CB, Sanzone, AG, Camuso, M, Henley, MB. Treatment of proximal humeral fractures with Polarus nail fixation. J shoulder Elbow Surg 2004;13:191-5. Google Scholar, Crossref, Medline, ISI

26. Bjorkenheim, JM, Pajarinen, J, Savolainen, V. Internal fixation of proximal humeral fractures with a locking compression plate: A retrospective evaluation of 72 patients followed for a minimum of 1 year. Acta Orthop Scand 2004:75:741-5. Google Scholar, Crossref, Medline

27. Koukakis, A, Apostolou, CD, Taneja, T, Korres, DS, Amini, A. Fixation of proximal humerus fractures using the PHILOS plate: Early experience. Clin Orthop Relat Res 2006;442:115-20. Google Scholar, Crossref, Medline, ISI

28. Moonot, P, Ashwood, N, Hamlet, M. Early results for treatment of three- and four-part fractures of the proximal humerus using the PHILOS plate system. J Bone Joint Surg Br 2007;89:1206-9. Google Scholar, Crossref, Medline

29. Frangen, TM, Muller, EJ, Dudda, M, Arens, S, Muhr, G, Kalicke, T. Proximal humeral fractures in geriatric patients. Is the angle-stable plate osteosynthesis really a breakthrough? Acta Orthop Belg 2007;73:571-9. Google Scholar, Medline, ISI

30. Voigt, C, Woltmann, A, Partenheimer, A, Lill, H. Management of complications after angularly stable locking proximal humerus plate fixation [in German]. Chirurg 2007;78:40-6. Google Scholar, Crossref, Medline, ISI

31. Gardner, MJ, Weil, Y, Barker, JU, Kelly, BT, Helfet, DL, Lorich, DG. The importance of medial support in locked plating of proximal humerus fractures. J Orthop Trauma 2007;21:185-91. Google Scholar, Crossref, Medline, ISI. 